\title{
7 Peninsular Pronghorn Conservation: Too Many Paradigms, Too Few Indicators
}

\author{
Alejandro de las Heras and Marina Islas-Espinoza
}

\subsection{Introduction}

Pronghorn (Antilocapra americana) is the only member of the Antilocapridae family, and differs from bovids, cervids and other ruminants. It is found in North American deserts and grasslands (Fig. 1). Pronghorn is the second fastest land animal but can run for much longer than cheetah. Antilocapridae evolved in North America and were a successful family thanks to digestive and temperature regulation evolutions. These evolutions probably were a response to climate becoming highly seasonal about 34 million years ago, with glaciations alternating every 41-100 thousand years with temperatures slightly warmer than today, and millennial cycles of $2^{\circ} \mathrm{C}$ local cooling (Maslin, 2009). Lacking equivalent temperature regulation equus including horses came close to extinction (Mitchell and Lust, 2008; Kulemzina et al., 2014).

During the $19^{\text {th }}$ century the pronghorn population plummeted from 35 million to 20 thousand. From 1924 however, the population increased to 700,000, most of them in the US and less than 2500 in Mexico, where population is seemingly declining (Hoffmann et al., 2008), despite hunting prohibition everywhere in Mexico since 1922 (INE, 2000). All Mexican pronghorn are protected under the Convention on International Trade in Endangered Species (CITES) Appendix I (CITES and UNEP, 2009). In the US, subspecies A. americana sonoriensis is protected under the Endangered Species Act, ESA (US FWS, 1967). Another subspecies, also protected in Mexico is A. americana peninsularis (peninsularis henceforth), mostly present in El Vizcaino Biosphere Reserve in the Baja Peninsula (Fig. 2) and struggling to return to its 500-head 1925 population (INE, 2000).

Disturbingly, flagship protected areas in North America, such as Banff, Yellowstone and El Vizcaino have failed to provide a thriving environment for pronghorn and other ESA big game species (Berger et al., 2008; Hebblewhite et al., 2009). The aim of this study was to explore the drivers of such failures and derive a minimal set of indicators to assess state and threats, conservation malpractices, transparency and accountability.

To understand the failure of peninsularis to grow demographically despite two decades of intensive protection, this chapter firstly stacked the practice and theory of conservation against each other. Secondly, a knowledge network experiment identified short-term solutions to management issues. Knowledge systems are networks of actors and organizations that link knowledge and knowhow with action (McCullough and 
Matson, 2011). Finally, the foregoing elements (state, threats, management practices, assumptions and paradigms), representative of the first decade of implementation of El Vizcaino management plan (published as INE, 2000), as well as theoretical and practical recommendations, were used to derive a minimal set of essential indicators for use in improved management practices, and to inform long-term stakeholder participation (Scheme 1).

The state of captive, and free-roaming but fed, peninsularis was ascertained based on fitness and health data. Immediate threats to the populations were identified using breeding records and digital geographic information. These were then linked to a list of ongoing management practices in El Vizcaino. The underlying assumptions of practices were teased out of the lingo used in work conversations during nine continuous months with the personnel, leaders and non-governmental organizations (NGO) representatives in charge of the intensive management of peninsularis. Assumptions are working simplifications of paradigms in conservation disciplines; they are inherited from contact with external advisors or with other wildlife management projects. Such paradigms were identified in explicit documents (zoo association guidelines and park management plans), derived from long-term interactions with professionals (veterinaries), or resulted from research (on ranching in El Vizcaino, de las Heras et al., 2014). Others were deduced from work conversations with hunting guides (in the bighorn sheep project in El Vizcaino).

\subsection{Peninsularis State And Threats}

Peninsularis is probably below the expected recovery target of 500 head by 2010: 200 are in the wild (AZA Antelope and Giraffe Advisory Group, 2008) and 268 under management (daily head counts in La Choya peninsula, Fig. 2), of which 165 roam freely and 103 are captive (64 males, 33 females and 6 juveniles, separated in 3 enclosures). Mortality in the enclosed population during the 9-month observation period amounted to 2 males and 1 female (8, 1 and 1 years-old), all killed by conspecifics. From February 2007, fawns were raised in captivity, the youngest being 2 days old at capture. In 2008, 30 fawns were born but 19 had died from clostridiosis by March or had been euthanized; survival was 33\% at weaning. No births were recorded in 2009-2010. Fawn survival at weaning in Yellowstone was 5-15\% and 26-44\% (in absence and presence of wolves, respectively; Berger et al., 2008) and 51-100\% in three reintroductions in Mexico from Wyoming (Cancino Hernández, 2006). The dead 1-year-old female was the only 2007-2010 recorded recruit but she never got impregnated. With 2 surviving fawns among those born in 2007-2010, survival at maturity was 4-15\%.

Moderate Eimeria parasitosis (mild in enclosed males and severe in females) was observed (laboratory analysis by A. Barbabosa). Painful hooves were also present due to lack of wear in the sandy enclosure terrain, which added to probable arthritic and skeletal issues related to copper (Cu) deficiency (Fig. 1). Cu:Zn and other nutritional 


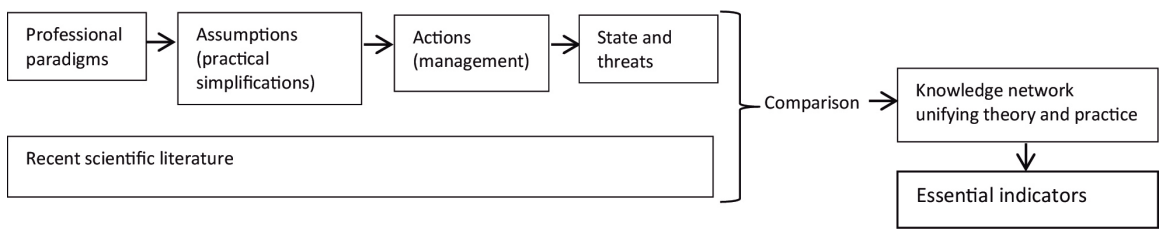

Scheme 1: Method.
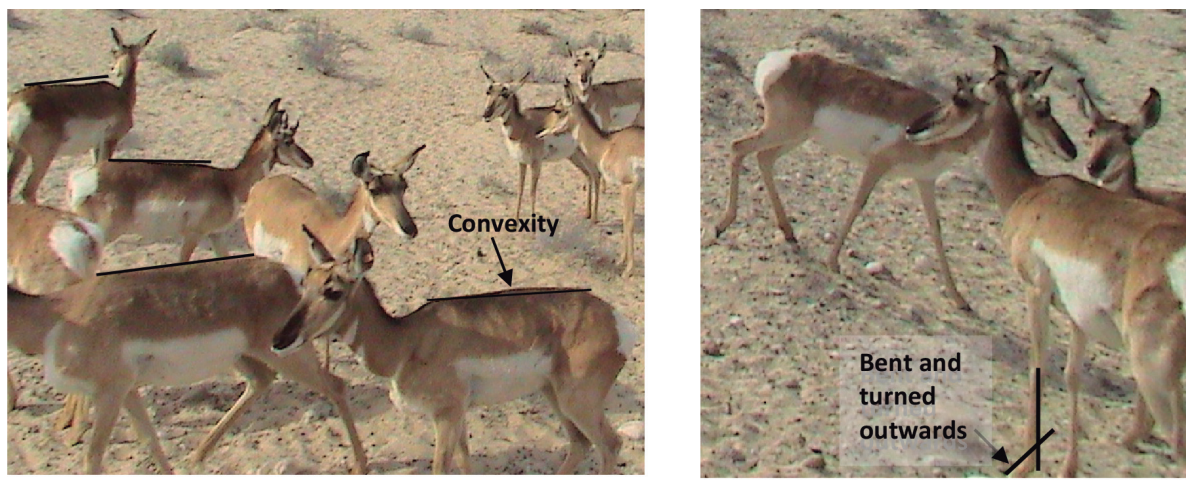

Figure 1: Clinical signs of Cu deficit. Convex backs and feet problems (bent, moving sideways while walking, turned inwards or outwards, difficult gait), hair problems (discolored around the eyes, ill-delimited hair colors, stiff hair) were observed in videos and pictures of free-roaming individuals in La Choya. Left: Convex back as opposed to flat backs. Right: Animal with straight back and good hair (even, intense color, good separation between colors in flank and hind quarters) but bent distal segment of front leg compared to the individual walking down (M. Huerta personal communication) (CPhotos by A. de las Heras).

imbalances could lead to low sperm and ovule quality, embryo losses and low resistance to clostridiosis (M. Huerta, R. Rangel personal communication). Emotionalbehavioral health issues were stereotypies (repetitive behavior of some individuals near the fence) and the deadly episodes referred to above.

The foregoing are signs of probable nutritional imbalance in the alfalfa (Medicago sativa) diet fed by humans. As to desert vegetation patchiness, it had reproductive implications: flushing or extra food consumed prior to breeding was only likely to happen if peninsularis roamed a wide range after rainfall (Fig. 2, left). Contrariwise, flushing was limited in a captive environment (Fig. 2, right); high protein alfalfa inputs did not compensate for nutrients available in the wild.

Access to nutrients was also restricted in the multiply fragmented habitat: by 1973 the trans-peninsular road cut off the western hyperarid Vizcaino portion of desert from the slightly wetter Angelino-Loretano portion (Peinado et al., 2005) to the east. The core protected area dedicated to peninsularis protection in El Vizcaino lies in the hyperarid part (Fig. 3). 

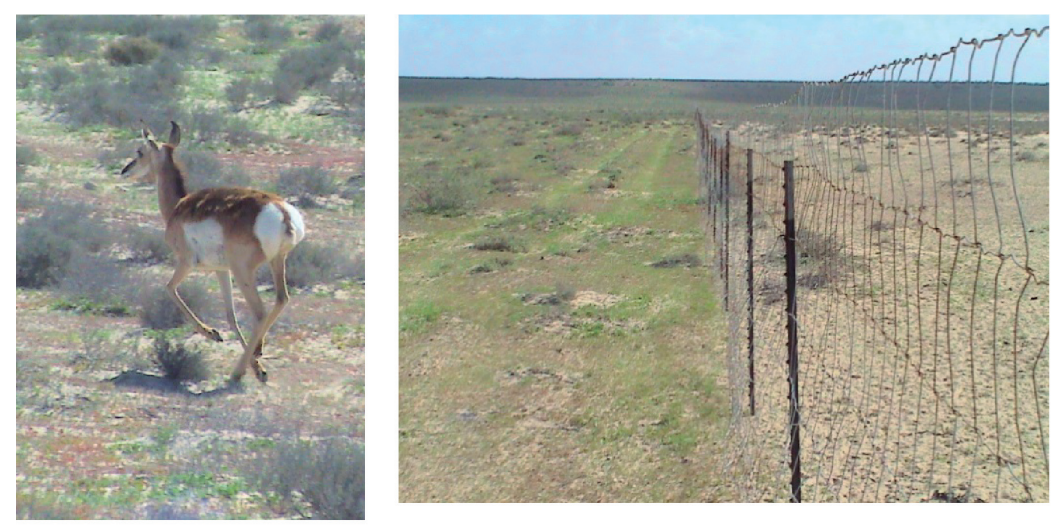

Figure 2: Seasonal microphillic brush and grass bloom after rainfall. Left: 2-8 inches tall vegetation after $7 \mathrm{~mm}$ January-February accumulated rainfall. Red and green vegetation only appear after rainfall. Grey vegetation is perennial. Right: Inside the fence, grazed seasonal microphyllic plants during the flush period closely resemble the usual scant vegetation cover. The difference with ungrazed vegetation outside the fence is patent. (@Photos by A. de las Heras).

Water salinity in well water, possibly due to seawater intrusion in the study area, likely increased peninsularis water requirements. Nutrient and water imbalances in the flushing, mating and breeding season were likely to affect sperm and ovule quality as well as embryo and newborn survival (R. Rangel personal communication). Water requirements varied considerably between seasons (Fig. 4) and so strongly contradicted the prevalent assumption of peninsularis reliance on the sole yearlong Pacific Ocean fog condensation on vegetation.

The foregoing issues were indicative of vulnerability to demographic and environmental stochasticities (risks affecting small biological populations). Genetic and catastrophic stochasticities could also be lurking (Table 1) since a metapopulation (set of spatially separated populations) survives if local extinction of a population is compensated for by migration from another population. This holds when sufficient density of local patches exists. In the case of peninsularis, wild and managed populations were cut off from each other; population growth in the latter was stalled. Seasonal migration between Vizcaino and Angelino-Loretano seasonal vegetation covers was halted. This impeded metapopulation dynamics and entailed enhanced extinction risk for wild and managed populations. Because metapopulation processes (reproduction and migration) were weak, strong population measures were warranted in the short term (such as assisted reproduction), as well as longer-term ecosystem measures (to restore gene flows and access to nutrients and free-standing freshwater). 


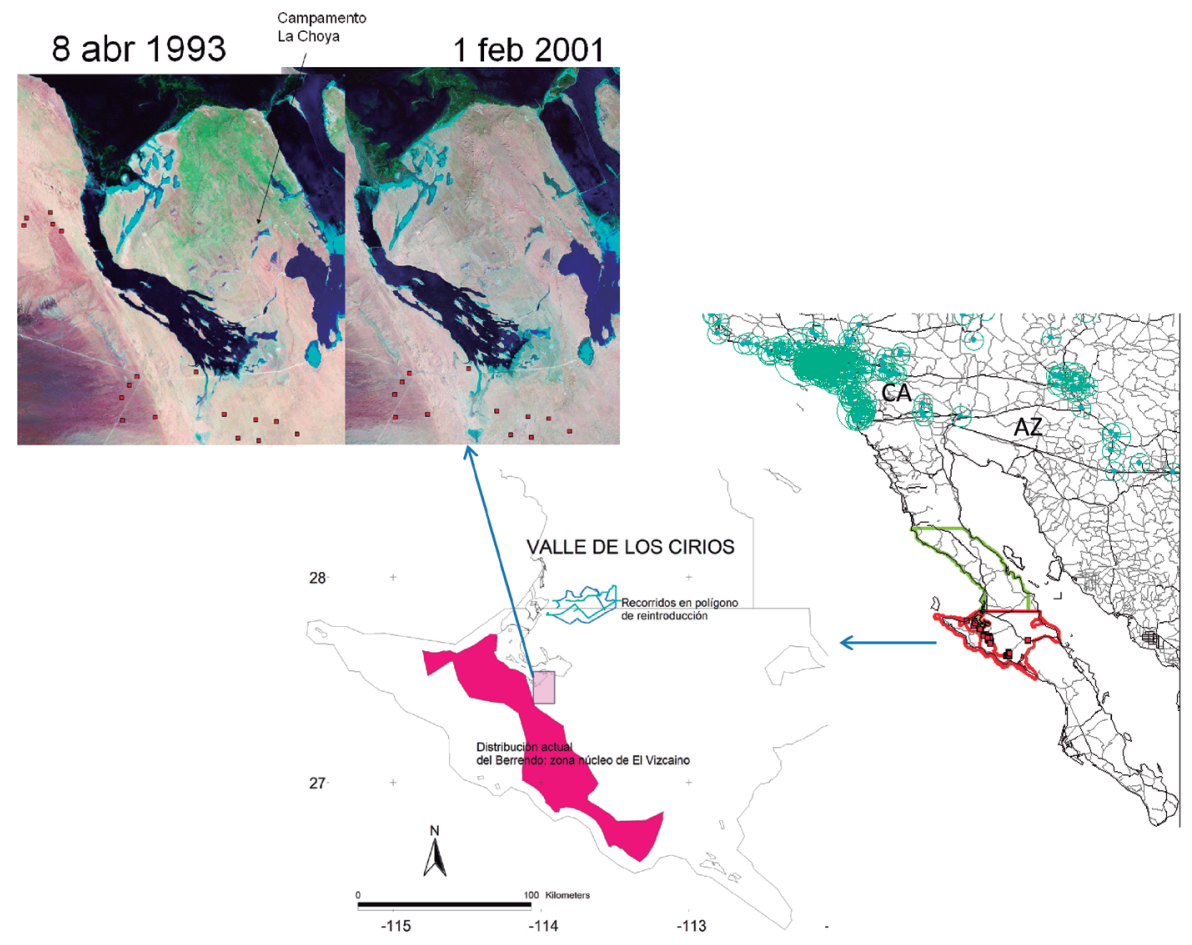

Figure 3: The multiply fragmented peninsularis habitat. Right: Animal movements out of the Baja peninsula are impeded by the US border, highways and metropolitan areas on either side of the border (CA: California; AZ: Arizona). Urban places are represented by circles proportional to their populations. The dry Vizcaino section of Cirios Protected Area (yellow outline) and El Vizcaino Biosphere Reserve (red outline, with red dots indicating sightings of peninsularis in the wild) are the conventionally accepted natural habitat of peninsularis (INE, 2000). Center: disturbances in the core area of the Biosphere Reserve dedicated to peninsularis (purple outline) include road traffic, reserve-authorized off-road racing, and extensive cattle ranching. La Choya's experiment was to be expanded to a 40-km-perimeter hunting enclosure (GPS tracks in blue) inside Valle de los Cirios protected area. Left: Typical of deserts, moisture is patchy in La Choya peninsula, recently cut out by saltworks (saltpans and a canal in the south) protecting the captive population from poaching but further fragmenting habitat and gene flows with wild populations.

\subsection{Conservation In Practice: Assumptions And Paradigms}

A list of observed peninsularis conservation activities was divided into 4 main groups and each was related to professional paradigms which encourage these activities (Table 2). The zoo paradigm was inherited by the peninsularis conservation project via contact with several US institutions, mostly the Cabeza Prieta National Wildlife Refuge in Arizona and its captive reproduction facility -under the auspices of the Binational Committee for the recovery of sonoriensis pronghorn-, and the Los Angeles 


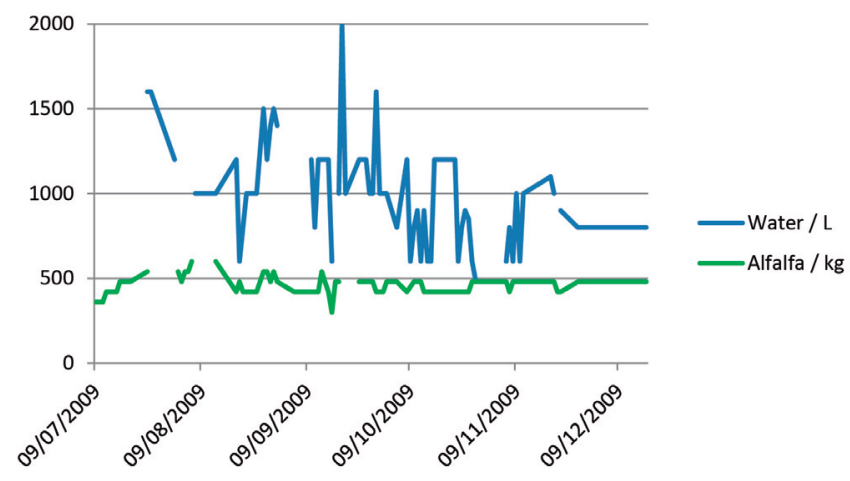

Figure 4: Water and alfalfa inputs to enclosed and free-roaming peninsularis. Ad libitum water supply was a reasonable estimate of water requirement. Water: feed 7-day and 14-day moving averages (not shown) showed a reduction from summer levels (3:1) to winter levels (1.5:1). Water was supplied by the saltworks as part of their cooperation with the Biosphere Reserve but was often too saline.

Table 1: Potential threats and associated stochasticities.

\begin{tabular}{|c|c|c|c|c|}
\hline Threats & $\begin{array}{l}\text { Stochasticities } \\
\text { Demographic }\end{array}$ & Genetic & Environmental & Catastrophes \\
\hline $\begin{array}{l}\text { Isolated } \\
\text { populations }\end{array}$ & $\begin{array}{l}\text { Reproductive } \\
\text { failure, } \\
\text { accidental } \\
\text { mortality }\end{array}$ & $\begin{array}{l}\text { Inbreeding, } \\
\text { local extinction }\end{array}$ & $\begin{array}{l}\text { Fragmented, incomplete } \\
\text { ecosystem. Restricted access } \\
\text { to very patchy vegetation. } \\
\text { Climate variation impact } \\
\text { strongest in driest remnant } \\
\text { wild habitat }\end{array}$ & $\begin{array}{l}\text { Extreme draughts } \\
\text { under climate } \\
\text { change }\end{array}$ \\
\hline Zoonoses & & & $\begin{array}{l}\text { Contamination by livestock } \\
\text { and ranchers handling } \\
\text { peninsularis }\end{array}$ & $\begin{array}{l}\text { Epizootics. } \\
\text { Nutritional } \\
\text { deficiencies } \\
\text { diminish resistance }\end{array}$ \\
\hline Poaching & $\begin{array}{l}\text { Increases } \\
\text { mortality, } \\
\text { decreases } \\
\text { reproduction }\end{array}$ & $\begin{array}{l}\text { Affects } \\
\text { the 'best' } \\
\text { phenotype, } \\
\text { not diseased } \\
\text { individuals }\end{array}$ & & \\
\hline Domestication & & & $\begin{array}{l}\text { Habituation to human } \\
\text { presence. Use of facilities as } \\
\text { shield against predators }\end{array}$ & $\begin{array}{l}\text { Human breeding: } \\
\text { decreased immunity, } \\
\text { increased infections }\end{array}$ \\
\hline Privatization & $\begin{array}{l}\text { Lack of } \\
\text { transparency } \\
\text { on recovery } \\
\text { trend. Scarcity } \\
\text { management } \\
\text { secures funds }\end{array}$ & $\begin{array}{l}\text { Purity of } \\
\text { subspecies } \\
\text { preferred } \\
\text { over genetic } \\
\text { diversity. } \\
\text { No assisted } \\
\text { reproduction }\end{array}$ & $\begin{array}{l}\text { Fencing, stereotypies, excess } \\
\text { density, injuries and death }\end{array}$ & \\
\hline
\end{tabular}


Zoo. Upgrading of the peninsularis conservation project in the American Zoo and Aquarium Association (AZA) survey (Shurter and Fischer, 2006; AZA Antelope and Giraffe Advisory Group, 2008) probably meant conformity to AZA ex situ captivity, demographic, public appeal indicators, criteria and prescriptions.

The vet paradigm in its simplified form applied to livestock was also applied to peninsularis; it aims at production (individual biomass increase) and reproduction. Therapeutics is secondary and pathos (suffering) overlooked. The ranch, zoo and vet paradigms focus on demography, captivity and feed largely overlapped. The amount of feed and water were principal and food quality secondary. Mexican alfalfa exports to the US meant low-rate feed was bought. A project to produce alfalfa for peninsularis in Cirios would likely mean more compliance with the ranch paradigm.

In addition, peninsularis management obeyed Mexican wildlife bylaws (Reglamento General de Vida Silvestre) regulating 'wildlife management and utilization units' (unidades de manejo y aprovechamiento de la vida silvestre, UMA). The intended project emulating the successful bighorn sheep UMA in El Vizcaino was based on the hunt paradigm and corporate mitigation funds. Both bighorn and pronghorn are two of the five ESA big game species (the Grand Slam in hunting parlance). Hunting UMAs assume that replacement by man of senescent dominant males improves the genetic pool, that man as keystone species can supplant all predators, and that human protection is better than ecosystem balance. Poaching, in addition, is commonplace in El Vizcaino (INE, 2000).

The park paradigm dominant in the US conservation model has spread worldwide and in particular inspires the core areas of Biosphere Reserves. This paradigm relies on removing humans from wilderness, but it makes large allowance for disturbance from tourism. The park paradigm could be traced in all managing activities (Table 2). The Biosphere authorities however were largely sidelined by the peninsularis highprofile project, funded by Ford Motor Co initially with a 400 thousand US dollar grant in 1997 (INE, 2000) and operated by an NGO which also managed the World Bank Global Environmental Facility funds for 27 Mexican protected areas. Still El Vizcaino contributed most of the workers of the project. The NGO paradigm was patent in the resource management tier of the project (Table 2). The NGO paradigm however seemed to face a commitment dilemma: On the one hand, caring for the animals; on the other hand managing (i.e. maintaining) scarcity of the subspecies, to keep funds flowing to this and other conservation programs. The NGO paradigm upheld the importance of the subspecies over free specimens. Sensitivity to reputational risk was noticeable in the reluctance to carry out censuses which could show failure to achieve recovery targets. Autonomy of the peninsularis project was also noticeable in its absence from the agenda of meetings of El Vizcaino overseeing committee. 
Table 2: Summary of conservation activities. Square brackets: underlying paradigms. Parentheses: Activities not carried out.

\begin{tabular}{|c|c|c|c|}
\hline $\begin{array}{l}\text { Managing populations } \\
\text { [Zoo, Vet, Park] }\end{array}$ & $\begin{array}{l}\text { Medicating } \\
\text { [Vet] }\end{array}$ & $\begin{array}{l}\text { Feeding and watering } \\
\text { [Vet, Ranch] }\end{array}$ & $\begin{array}{l}\text { Managing resources } \\
\text { [NGO, Hunt] }\end{array}$ \\
\hline $\begin{array}{l}\text { Fencing and building } \\
\text { facilities }\end{array}$ & $\begin{array}{l}\text { During breeding. } \\
\text { Keeping records }\end{array}$ & $\begin{array}{l}\text { Transporting alfalfa over } \\
1000 \mathrm{~km}\end{array}$ & Lease from landholders \\
\hline $\begin{array}{l}\text { Marking individuals. } \\
\text { Separating sexes and } \\
\text { juveniles }\end{array}$ & $\begin{array}{l}\text { (Assisted } \\
\text { reproduction) }\end{array}$ & $\begin{array}{l}\text { Negotiating water truck } \\
\text { pipes with the saltworks } \\
\text { corporation }\end{array}$ & $\begin{array}{l}\text { Negotiate funds with } \\
\text { corporations, NGO and } \\
\text { individuals }\end{array}$ \\
\hline $\begin{array}{l}\text { Chute-capture. Capture of } \\
\text { fawns. Transport to captive } \\
\text { management facilities }\end{array}$ & & $\begin{array}{l}\text { Feeding and watering } \\
\text { daily. Occasional } \\
\text { cleaning of enclosures }\end{array}$ & $\begin{array}{l}\text { Negotiate easement with } \\
\text { NGOs and landholders }\end{array}$ \\
\hline $\begin{array}{l}\text { Surveys. Head counts. } \\
\text { Counting newborn fawns. } \\
\text { Animal and vegetation } \\
\text { studies. (Census) }\end{array}$ & & $\begin{array}{l}\text { Providing minerals and } \\
\text { pellets }\end{array}$ & $\begin{array}{l}\text { Negotiate survey, } \\
\text { autonomy, manpower } \\
\text { and truck from Reserve }\end{array}$ \\
\hline $\begin{array}{l}\text { Fielding coyotes. } \\
\text { Surveillance }\end{array}$ & & Keeping records & $\begin{array}{l}\text { Negotiate with local } \\
\text { alfalfa producers }\end{array}$ \\
\hline $\begin{array}{l}\text { Managing scarcity: } \\
\text { defending the existence, } \\
\text { and purity, of a subspecies }\end{array}$ & & & $\begin{array}{l}\text { Public relations: hosting } \\
\text { tourists and press }\end{array}$ \\
\hline
\end{tabular}

Table 3: Overlapping assumptions and paradigms. Domestication (D) and privatization (P) as consequences.

\begin{tabular}{|c|c|c|}
\hline PRACTICE & ASSUMPTION & PARADIGM \\
\hline D,PCaptivity & $\begin{array}{l}\text { Umwelt and telos irrelevant. Habitat area irrelevant. } \\
\text { Protection against coyotes, poaching }\end{array}$ & Zoo, ranch \\
\hline $\mathrm{D}, \mathrm{P}$ Breeding & Fawns born in captivity are UMA property & UMA \\
\hline${ }^{D}$ Selection by man & $\begin{array}{l}\text { Phenotype (outer aspect) preferred over heterozygosis } \\
\text { (genetic diversity), selection by man not by natural } \\
\text { evolution }\end{array}$ & Vet, ranch \\
\hline${ }^{D}$ Feed and water & Protein first in animal production. Salinity irrelevant & Vet, ranch \\
\hline DTourism & Disturbance is negligible & Zoo, park, hunt \\
\hline${ }^{P}$ Autonomy & Insiders/outsiders dichotomy & NGO \\
\hline $\begin{array}{l}\text { Single-species } \\
\text { management }\end{array}$ & $\begin{array}{l}\text { Pronghorn as desert gardener. Valid umbrella species. } \\
\text { Hyper-arid plains as original habitat. Carrying capacity } \\
\text { referred to one single species. Net herbivory effect } \\
\text { neglected }\end{array}$ & Park \\
\hline
\end{tabular}

Umwelt is the particular worldview of an animal species. Telos is what characterizes an animal species (its role in the environment and evolved fitness abilities). 
Overlapping assumptions and paradigms (Table 3) seemingly revealed domestication and privatization trends. Domestication use of baby bottle and formula, enclosure, overreliance on feed and human-supplied water, pronghorn use of human facilities as shield from coyotes, (see Berger, 2007) and privatization (ownership of UMA-born fawns, and lucrative hunting) were emergent properties potentially negating fitness in the wild. Whether domestication and privatization were intentional was unclear.

\subsection{Knowledge Network Short-Term Recommendations}

Peninsularis conservation had eluded catastrophic stochasticities, such as ungulate epizootics in adults, possibly thanks to isolation in La Choya. But in projected isolates north of the $28^{\text {th }}$ parallel, epizootics could be more probable in enclosures previously exposed to livestock. Isolation of peninsularis from workers who are also ranchers or live in ranching communities, or from exposed visitors, seemed difficult. Human breeding might worsen catastrophic stochasticities via isolation from mother colostrum and nutrient deficiency in feed.

To allay demographic and genetic stochasticities, until that time when sustainability is achieved through restoration of complete ecosystems, reproduction and recruitment (survival to sexual maturity) ought to be monitored and lapses prevented by recourse to assisted reproduction (which includes consanguinity and paternity analyses and artificial insemination). Human selection based on phenotype first and then on heterozygosis may allay the threat of genetic depression. It does not guarantee however the genotype most immune to diseases. Microsatellite analyses (Carling et al., 2003) would help determine allelic polymorphism (J.C. Vazquez personal communication). Tagging and microchip follow-up ought to help avoid consanguinity. Laparoscopic insemination and anesthesia could then be carried out by external practitioners committed to long-term cooperation (R. Rangel pers. comm.). Other future needs include sperm banks, mineral micronutrient analyses in feed, wild vegetation and blood (e.g. $\mathrm{Cu}, \mathrm{Zn}$, Se, Mo), as well as stress hormone analyses (cortisol and epinephrine).

\subsection{Longer-Term Need For Complete Ecosystems}

The importance of a complete environment for peninsularis was exemplified by a female and fawn after winter showers, when they were most averse to alfalfa feed, and occupied an Adam tree (Fouquieria diguetii) patch with abundant hare defecations to hide and mask smell from coyotes. This suggested awareness and use of a complete ecos, with intertwined telos and ethos (Fox, 2005), i.e. fulfillment of physical, behavioral and psychological requirements and roles in the ecosystem. 
Although absent from the zoo-vet-ranch paradigms, habitat is the most salient factor affecting the viability of small populations (Hebblewhite et al., 2009; Hoffmann et al., 2008; Lee and Jetz, 2011; Rodrigues et al., 2005). The assumption that peninsularis are gardeners of the desert interestingly points to seed dispersal and nutrient recycling via feces. Ungulate effects on plants however run the gamut from dispersal to alteration and mostly entail a net decrease in plant biomass (Cadenasso et al., 2002; Maron and Kauffman, 2006). Although ungulate impact seems proportional to nutrient content (Asner et al., 2009), impact of peninsularis on palatable shrubs (Atriplex canescens, Encelia farinose, Frankenia palmeri, Fouquieria diguetii) might also depend on soil water retention capacity and salt content. None of these shrubs is Baja- or Vizcaino-endemic (Peinado et al., 2005); this suggests a wider natural ecosystem for peninsularis than hyperarid and sometimes hypersaline Vizcaino.

Rather than gardeners -an anthropomorphic notion- ungulates are strong interactors (Soulé et al., 2003; Donlan et al., 2006) with direct and indirect (cascade) effects on the habitat and resource availability of other herbivores (insects, lizards, lagomorphs and rodents; Gibbens et al., 1993; Maron and Kauffman, 2006; Pringle et al., 2007), microbiota (soil biological crusts; Manier and Hobbs, 2006, and fungal plant symbionts; Clay et al., 2005), pollinators and dispersers, competing ungulates, and predators.

Although threat lists (IUCN - International Union for the Conservation of Nature - Red List, CITES and ESA) and the peninsularis project alike focus on organismal biology, the definition and unstable application of species concepts, the lack of knowledge of most species and the focus on population size are now strongly debated. Population and habitat are not sufficient criteria and ecological targets are pressingly needed; peninsularis as umbrella species is not sufficient to establish biodiversity conservation targets (Possingham et al., 2002; Reed et al., 2002). Ecosystem-level and multitrophic-level studies are essential in understanding extinction dynamics in endangered species (Hebblewhite et al., 2009).

As regards the park paradigm, naturalness criteria are defeated in practice by ubiquitous human presence; they are being supplanted by historical fidelity, autonomy of nature, ecological integrity, and resilience targets (Hobbs et al., 2010). As fitness in the wild may require larger gene flows than usually reckoned by population viability analyses (Reed et al., 2002), connectivity between patch populations is essential. Design of buffer zones, biological corridors and stepping stones in fragmented park habitats now requires experimental evidence in particular relating to wildlife movement, and a focus on animal complementarity in the face of cyclical and anthropogenic climate changes (Soulé et al., 2003; Chazdon et al., 2009; Woodruff, 2010). A radical response, rewilding or restoration of complete Pleistocene ecosystems, aims at devolving evolutionary capability (Donlan et al., 2006; Woodruff, 2010). Complete ecosystems include top-predators (keystone species, Soulé et al., 2003) preying on coyotes; in their absence, pronghorn fawn survival plummets (Berger et al., 2008). Reintroduction of top predators is critical for simplified 
ecosystems (Pringle et al., 2007). Rewilding of degraded rangelands more than rest alone requires restoring and sustaining natural processes (Curtin, 2002).

At a narrow timescale, pronghorn populations vary in relation to drought and winter severity; and water needs vary in relation to succulence of vegetation (Hoffmann et al., 2008). At a wider timescale, the drought trend (reviewed in de las Heras et al., 2014) indicates an increasingly dry Sonoran desert. The anatomic adaptations of pronghorn may not be sufficient when higher temperature and less humidity coincide with restricted movement in an ecosystem devoid of free-standing water, succulent vegetation, and keystone predators (wolves and pumas) to exert top-down control on pronghorn herbivory. Past monsoon Holocene switch-offs (ibid.) are cautionary tales for the North American monsoon that brings summer moisture to eastern Baja. The coincidence of stochasticities and systematic threats such as climate change bears resemblance with climatic and anthropogenic factors conspiring 50-10 thousand years ago in megafaunal and antilocaprid mortality (Koch and Barnosky, 2006).

\subsection{Discussion}

\subsubsection{Privatization And Information}

While the debate on ecosystem restoration has coalesced around rewilding and coupled human and natural systems, current human relationships with nature are driven by privatization. Privatization critiques relate firstly to the lack of information being issued by private initiatives, the need for independent reporting, oversight and accountability for the consequence of wilderness management (Alcorn et al., 2005; Igoe, 2007). Secondly, funds become a dominant logic of elite NGOs monopolizing donors while at the same time reducing participation of and coordination with other stakeholders. This overreliance on donations makes projects vulnerable to inherently unstable financial markets, donor interests, policies and fearful to offend or lose donors (Alcorn et al., 2005; More, 2005). Thirdly, self-interest leads to a defective view of our obligations to the future (Pezzey, 1989), and a focus on managing extinction which sidelines restoration and evolutionary processes (Donlan et al., 2006). Fourthly, restricted access is the mechanism for privatization. It assumes either the form of exclusion of visitors unwilling to pay when management is for profit, as in Yellowstone, Yosemite or in private easements in Patagonia (More, 2005; Carey, 2009), or the form of access restriction for local residents as in Canada, the US and South African game farms and protected areas (West et al., 2006; Healy, 2007). Fifthly, in contexts devoid of self-imposed rules and enforcement, "privatization is the worst possible fate" (Bowles et al., 1998; Terborgh, 2000). 


\subsubsection{Information And Stakeholders In Knowledge Networks}

In El Vizcaino Biosphere Reserve inhabitants are "marginalized by the very conservation process meant to engage them as key actors in promoting naturalresource protection" (Young, 1999). This runs counter the need in endangered species' recovery projects for interdisciplinary frameworks and teams, exchange of knowledge and resources to build research, management, assessment, and policy partnerships (Reed et al., 2002; Chazdon et al., 2009). Interim science and management reports must be shared among stakeholders and information shared on all issues in regular meetings and interactions (Hebblewhite et al., 2009). Participatory science can engage local residents in monitoring, reporting and discussion activities as ways of promoting awareness and action. This can deliver much more fine-grained information than large organizations relying on expert judgment and facing difficulties in meeting their pledges on open-access data and grass-root participation (Rodrigues et al., 2005). This however implies a shift in values from aversion to reputational risk (inherited from large donors) towards transparency, international and local accountability, and involvement of interested third parties. This is equivalent to a shift from the privatization trend to participatory science and practice.

Another way of participating is via conservation easements, whereby landholders have been seeking to protect their land rights from corporate mining interests in the allocated peninsularis habitat. Unused community land has also been relinquished by landholders in favor of the Biosphere Reserve (Harris, 2008). In such common asset trusts, users can make their own rules - often managing more successfully than private owners and legal parks - and produce freely available information and technologies enhancing and protecting public goods (Gibson et al., 2002; Hayes, 2006; Beddoe et al., 2009). This pooling of large land tracts and perpetuity easements is consistent with the IUCN definition of protected areas, and could in theory host Pleistocene rewilding or bioneering experiences - interventionist ecological management - and include the knowledge of local traditional communities, in a timeframe allowing for evolution to cope with climate change and other large-scale fluctuation factors (Donlan et al., 2006; Dudley, 2008; Woodruff, 2010).

Parks may not be the optimal governance structure for local conservation (Hayes, 2006) especially when power is lost to NGOs, prompting lack of coordination. The park and NGO paradigms also make too many concessions to resource extraction and to disturbances associated with tourism: in El Vizcaino's peninsularis core protected corridor, off-road tourism and races degrade the land (United Nations Environment Programme and World Conservation Monitoring Centre, 2008) but permits continue to be issued on account of good relations with the residents of the Reserve. The sensitivity of peninsularis to disturbances can be inferred by reference to death of two juveniles induced in 2009 by the presence of a photographer in the enclosures, or by peninsularis being relegated to the least hospitable habitat to avoid human presence. 
If however, international and local participation in rewilding make inroads and subvert the current park-and-NGO governance of wildlife, apparent contradictions could disappear between the necessity for very large undisturbed land tracts and local involvement. This is dependent on a set of indicators agreed upon in knowledge systems (Box 1). These indicators are intended to guide the assessment of conservation practices, ascertaining consistency with or justified departure from current literature consensuses, as well as facilitating knowledge networks. Specific indicators should be defined by stakeholder participation (see however the Appendix for a proposal).

BOX 1. Minimal set of indicators for network involvement and accountability

TIER1

State, long- and short-term threats,

and response indicators (stochasticities and systematic threats)

TIER 2

Ecos, telos and ethos indicators (disturbances),

short-term (recruitment, mortality and biometrics)

and longer-term (complete ecosystem restoration) indicators

TIER3

Knowledge network, malpractice, transparency and accountability indicators

\subsubsection{Indicators In Practice}

In theory, sustainability is indicated by the indefinitely continued existence of a living population, or more generally a natural stock (de las Heras, 2014). In practice, tallying, analyzing indicators, guiding collaboration and correcting decisions is a sequence of activities both time- and energy-consuming. Cost often makes it difficult to dedicate personnel to ensuring data quality, scope and depth. And so it is often felt that only a narrow set of indicators is needed. This attitude runs counter the comprehensive view of the natural and social environment which sustainability implies. This is further complicated by the need to quantitatively assess decisions against evolving, qualitative, scientific knowledge.

The way out of this conundrum is to rely on a larger set of skills and to standardize the loop of information-communication-collaboration implicit in a knowledge network. The latter will identify the indicators that are relevant and practical to collect, assess conservation efforts, and implement corrective and preemptive measures (see Appendix for a data collection instrument). This loop would likely steer a conservation program away from management and into decision-making with identifiable tradeoffs. Strategic tradeoffs may involve funding or public relations conflicts. Field tradeoffs 
arise when indicators are too difficult to obtain and hamper timely field decisions, in which cases proxies are required.

Finally caution is warranted in a series of common situations. Firstly, tradeoffs are sometimes solved by forcing data to comply with goals. This happens when pressure mounts and goals are over-optimistic. Secondly, when problems are illspecified, indicators are of little help. This occurs, as exposed here, when standard theories and responses bias analyses or when managers supply all the indicators, also producing bias. Finally hiring specialists as the third party responsible for indicators poses two diverging problems: outsiders have to adjust their skills and knowledge to the situations at hand or else, conservation actions have to adjust to the specialists' framework. Again, a workaround is to establish long-term links with specialists within a knowledge network.

\subsubsection{Indicators, Models, Metrics Or Unified Theory?}

NGO peninsularis management lacked indicators. More generally El Vizcaino lacked organized datasets of permit-holders, temporary work, funding, wildlife and spatial information. We took a detour and instead of stating directly what relevant indicators might be, we devised a method for collectively delineating short-term measures and indicators, and outlining long-term solutions from a comparison with available literature.

This approach to participatory science relying on indicators differed from statistical models aiming at unraveling the covariates of extinction (Lee and Jetz, 2011) which require, but do not always use, good quality data. Other model issues are that they rely on implicit assumptions and software and so yield different results (Reed et al., 2002; CONABIO, 2007). Deep issues are also involved in expert ranking of the importance of biological taxa and nationwide top-down prioritization, disregarding peninsular biogeography.

Metrics, or sets of interrelated indicators, although desirable require good indicator characteristics (unequivocal interpretation, assumption-free estimation, easy replication and easy validation). Indicators and metrics have an important practical role to play towards the acutely needed unified theory in conservation.

\subsection{Conclusions}

Demographic growth indicators called for a reconsideration of practices in Antilocapra americana peninsularis recovery. Qualitative indicators evidenced underlying assumptions and paradigms lagging behind recent (molecular and ecological) science. In particular interactions with zoo professionals had led to an 
incipient domestication trend. The mainstream NGO paradigm seemed conducive to a privatization trend, in which recovery was delayed on account of continuation of donations. Recent conservation literature recommends caution against privatization and a shift in focus from population to a complete ecosystem where strong interactors like peninsularis are in balance with plants, the other herbivores and predators. A simplified view has confused the allotted peninsularis area in the Biosphere Reserve (the hyperarid Vizcaino area) with its natural habitat. The eastern summer and western winter rainfalls, and the extremely developed adaptation of peninsularis for migration, suggest a much larger and richer ecosystem. Restoration of a complete ecosystem calls for participation of landholders in perpetuity easements. Short-term solutions to stalled demographic growth include assisted reproduction and balanced nutrition. Population growth and easements are not independent and cooperation between actors calls for a durable knowledge network. In the latter, exchange of key indicators supports participatory decisions.

The relative ease with which these indicators can be obtained and validated suggests their use in many recovery projects. A windfall for scientists and concerned citizens, if project documentation becomes widespread would be the possibility to assess the global response to the current extinction crisis, and especially the efficacy of Biosphere Reserves in species and ecosystem recovery.

Conservation practice and theory should systematically be compared. Accountability, transparency and stakeholder involvement in knowledge systems should circumvent ingrained paradigms. They require an appropriate set of indicators.

At this point recommendations are usually in order. However, in line with best knowledge network and participatory practices, recommendations should be made after the stakeholders have identified the problems to be solved. This chapter is best considered a 'conciliatory participation' typical of intermediary roles in knowledge networks. These intermediary roles have often facilitated communication among stakeholders, just as indicators have been a requisite for objective problem identification and problem-solving. 


\section{Appendix: Pronghorn Management Questionnaire (Essential Indicators)}

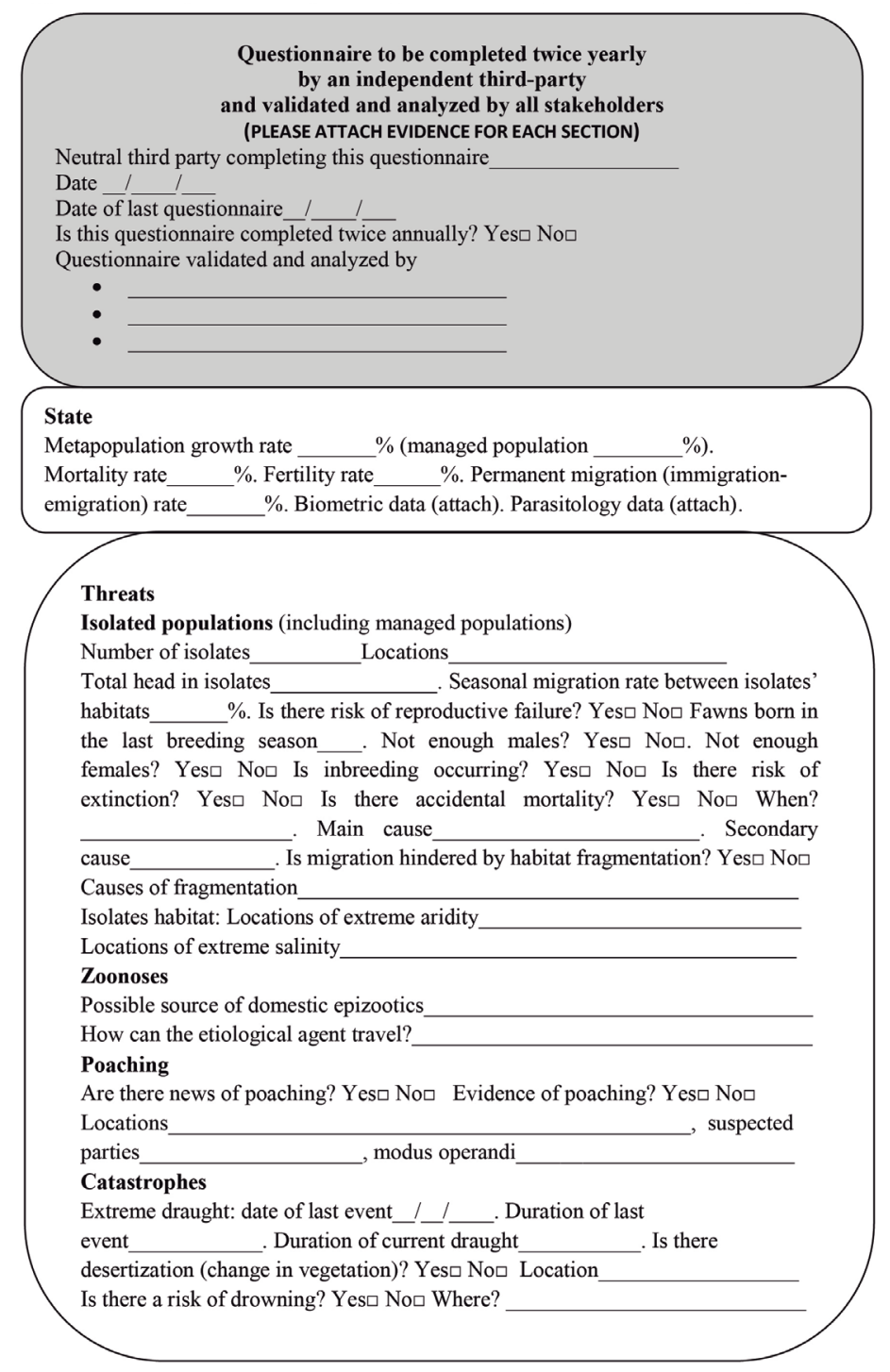




\section{Management actions (MA)}

Science-based (attach list and justify)

Non-science-based (attach list and justify)

Food provision (specify diet including macro and micronutrients, amount, and frequency of supply)

Water provision (specify salinity, amount and frequency of supply)

Number of food providers_. Number of water providers

Number of food supplement providers_. Number of medicine providers . Number of funding sources

Specify leases and their duration

Specify (perpetuity) easements

\section{Assessment of MA}

Expected demographic and genetic impact of MA (attach).

Injuries: incidence , prevalence

Expected domestication effects? Yes $\square$ No $\square$ Habituation to human presence? Yes $\square$ No $\square$ Use of facilities as shield against predators? Yes $\square$ No $\square$ Human breeding? Yes $\square$ No $\square$ Assisted reproduction? Yes $\square$ No $\square$ Stereotypies? Yes $\square$ No $\square$ Density in enclosures Are the populations dependent on man? Yes $\square$ Nor

Expected privatization effects? Yes $\square$ No $\square$ Transparency on recovery trend? Yes $\square$ Nor Benefits stemming from scarcity

\section{Corrective and preemptive MA}

Deviations (attach)

Corrections (attach)

Anticipated deviations (attach)

Preemptive actions (attach)

\section{Existence of knowledge network}

Stakeholders (attach list). Involved stakeholders (attach list). Frequency of meetings Frequency of informal dialogues with each stakeholder group

Are decisions made on a single species? Yes $\square$ No $\square$ Specify net primary productivity of the habitat landscapes (attach) Specify carrying capacity for the species ; for all ungulates ; for predators

Specify the trophic network of the protected species, including meso and apex predators (attach). Specify the functional diversity of herbivores in the habitat (attach). Are decisions made based on information about a complete ecosystem? Yes $\square$ Nor Specify the net herbivory effect (attach).

Specify invasive research methods 


\section{References}

Alcorn, J. B., Luque, A., \& Weisman, W., et al. (2005). Non-Governmental Organizations and protected area governance. Governance Stream of the Vth World Parks Congress, Durban, South Africa, Parks Canada and IUCN/WCPA. (pp. 1-44).

Asner, G. P., Levick, S. R., \& Kennedy-Bowdoin, T., et al. (2009). Large-scale impacts of herbivores on the structural diversity of African savannas. PNAS, 106, 4947-4952.

AZA Antelope \& Giraffe Advisory Group. (2008). AZA Antelope and Giraffe Advisory Group Regional Collection Plan. Fifth edition.

Beddoe, R., Costanza, R., \& Farley, J., et al. (2009). Overcoming systemic roadblocks to sustainability: The evolutionary redesign of worldviews, institutions, and technologies. PNAS, 106, 2483-2489.

Berger, J. (2007). Fear, human shields and the redistribution of prey and predators in protected areas. Biology Letters, 3, 620-623.

Berger, K. M., Gese, E. M., \& Berger, J. (2008). Indirect effects and traditional trophic cascades: A test involving wolves, coyotes, and pronghorn. Ecology, 89, 818-828.

Bowles, I. A., Rosenfeld, A. B. \& Sugal, C. A., et al. (1998). Natural resource extraction in the Latin Tropics: A recent wave of investment poses challenges for biodiversity conservation. Policy Briefs. Conservation International, Spring(1), 1-7.

Cadenasso, M., Pickett, S., \& Morin, P. (2002). Experimental test of the role of mammalian herbivores on old field succession: Community structure and seedling survival. Journal of the Torrey Botanical Society, 129, 228-237.

Cancino Hernández, J. de J. (2006). Primer informe general de las transferencias de crías de berrendo del estado de Wyoming, EEUU a México.

Carey, M. (2009). Latin American environmental history: current trends, interdisciplinary insights, and future directions. Environmental History, 14, 221-252.

Carling, M., Passavant, C., \& Byers, J. (2003). DNA microsatellites of pronghorn (Antilocapra americana). Molecular Ecology Notes, 1-2. doi:10.1046/j.1471-8286

Chazdon, R. L., Harvey, C. A. \& Komar, O., et al. (2009). Beyond reserves: A research agenda for conserving biodiversity in human-modified tropical landscapes. Biotropica, 41(2), 142-153.

CITES \& UNEP. (2009). Convention on International Trade in Endangered Species of Wild Fauna and Flora. Appendices I, II and III. Valid from 22 May 2009, 41(May), 1-41.

Clay, K., Holah, J., \& Rudgers, J. A. (2005). Herbivores cause a rapid increase in hereditary symbiosis and alter plant community composition. PNAS, 102, 12465-12470.

CONABIO (2007). Análisis de vacíos y omisiones en conservación de la biodiversidad terrestre de México: espacios y especies (p. 127). Mexico City: Conabio.

Curtin, C. G. (2002). Livestock grazing, rest, and restoration in arid landscapes. Conservation Biology, 16, 840-842.

De las Heras, A., Rodriguez, M. A., \& Islas-Espinoza, M. (2014). Water appropriation and ecosystem stewardship in the Baja desert. Change and Adaption in Socio-Ecological Systems, 1: 63-73.

De las Heras, A, (2014). Preface. In A. de las Heras (Ed.) Sustainability Science and Technology. An Introduction. Boca Raton, Florida: CRC Press.

Donlan, C. J., Berger, J., \& Bock, C. E., et al. (2006). Pleistocene rewilding: An optimistic agenda for twenty-first century conservation. The American Naturalist, 168, 660-681.

Dudley, N. (2008). Guidelines for Applying Protected Area Management Categories. IUCN, Gland, Switzerland. Retrieved from https://portals.iucn.org/library/sites/library/files/documents/ PAG-021.pdf

Fox, M. W. (2005). Interrelationships between mental and physical health: the mind-body connection. In F. D. McMillan (Ed.), Mental health and well-being in animals (pp. 113-125). Ames, lowa: Blackwell Publishing. 
Gibbens, R., Havstad, K., \& Billheimer, D., et al. (1993). Creosotebush vegeation after 50 years of lagomorph exclusion. Oecologia, 94, 210-217.

Gibson, C. C., Lehoucq, F. E., \& Williams, J. T. (2002). Does privatization protect natural resources? Property rights and forests in Guatemala. Social Science Quarterly, 83, 206-225.

Harris, S. L. (2008). Conservation easements on Mexican ejidos: An alternative model for indigenous peoples. The Evergreen State College.

Hayes, T. M. (2006). Parks, people, and forest protection: An institutional assessment of the effectiveness of protected areas. World Development, 34, 2064-2075. doi:10.1016/j. worlddev.2006.03.002

Healy, R. G. (2007). Parks and people in North America-one hundred and thirty five years of change. Policy Matters, 15, 261-272.

Hebblewhite, M., White, C., \& Musiani, M. (2009). Revisiting extinction in national parks: mountain caribou in Banff. Conservation Biology, 24, 341-344. doi:10.1111/j.1523-1739.2009.01343.x

Hobbs, R. J., Cole, D. N., \& Yung, L., et al. (2010). Guiding concepts for park and wilderness stewardship in an era of global environmental change. Frontiers in Ecology and the Environment, 8, 483-490. doi:10.1890/090089

Hoffmann, M., Byers, J., \& Beckmann, J. (2008). Antilocapra americana. The IUCN Red List of Threatened Species. Version 2014.2.

Igoe, J. (2007). Human rights, conservation and the privatization of sovereignty in Africa - a discussion of recent changes in Tanzania. Policy Matters, 15, 241-254.

INE. (2000). Programa de manejo. Reserva de la biosfera El Vizcaíno (p. 243). Mexico City: Instituto Nacional de Ecología.

Koch, P. L., \& Barnosky, A. D. (2006). Late Quaternary Extinctions: State of the debate. Annual Review of Ecology, Evolution, and Systematics, 37, 215-250. doi:10.1146/annurev. ecolsys.34.011802.132415

Kulemzina, A. I., Perelman, P. L., \& Grafodatskaya, D. A., et al. (2014). Comparative chromosome painting of pronghorn (Antilocapra americana) and saola (Pseudoryx nghetinhensis) karyotypes with human and dromedary camel probes. BMC Genetics, 15(68), 1-8. doi:10.1186/1471-215615-68

Lee, T. M., \& Jetz, W. (2011). Unravelling the structure of species extinction risk for predictive conservation science. Proceedings of the Royal Society B Biological Sciences, 278, 1329-1338. doi:10.1098/rspb.2010.1877

Manier, D. J., \& Hobbs, N. T. (2006). Large herbivores influence the composition and diversity of shrub-steppe communities in the Rocky Mountains, USA. Oecologia, 146, 641-651. doi:10.1007/s00442-005-0065-9

Maron, J. L., \& Kauffman, M. J. (2006). Habitat-specific impacts of multiple consumers on plant population dynamics. Ecology, 87, 113-124.

Maslin, M. (2009). Global warming. A very short introduction (p. 192). Oxford: Oxford University Press.

McCullough, E. B., \& Matson, P. A. (2011). Evolution of the knowledge system for agricultural development in the Yaqui Valley, Sonora, Mexico. PNAS Early Edition, 1-6. doi:10.1073/ pnas.1011602108

Mitchell, G., \& Lust, A. (2008). The carotid rete and artiodactyl success. Biology Letters, 4, 415-418. doi:10.1098/rsbl.2008.0138

More, T. A. (2005). From Public to Private: Five concepts of park management and their consequences. The George Wright Forum, 22, 12-20.

Peinado, M., Delgadillo, J., \& Aguirre, J. L. (2005). Plant associations of El Vizcaíno Biosphere Reserve, Baja California Sur, Mexico. The Southwestern Naturalist, 50, 129-149.

Pezzey, J. (1989) Economic analysis of sustainable growth and sustainable development. World Bank Policy Planning and Research Staff, Environment Department, Working paper 15, 88 pp. 
Possingham, H. P., Andelman, S. J., \& Burgman, M. A., et al. (2002). Limits to the use of threatened species lists. Trends in Ecology \& Evolution, 17, 503-507.

Pringle, R. M., Young, T. P., \& Rubenstein, D. I., et al. (2007). Herbivore-initiated interaction cascades and their modulation by productivity in an African savanna. PNAS, 104, 193-197.

Reed, J. M., Mills, L. S., \& Dunning Jr, J. B., et al. (2002). Emerging issues in population viability analysis. Conservation Biology, 16, 7-19.

Rodrigues, A. S. L., Pilgrim, J. D., \& Lamoreux, J. F., et al. (2005). The value of the IUCN Red List for conservation. Trends in Ecology \& Evolution, 21(2), 71-76. doi:10.1016/j.tree.2005.10.010

Shurter, S., \& Fischer, M. (2006). AZA Antelope and Giraffe Advisory Group Regional Collection Plan.

Soulé, M. E., Estes, J. A., \& Berger, J., et al. (2003). Ecological effectiveness: Conservation goals for interactive species. Conservation Biology, 17, 1238-1250.

Terborgh, J. (2000). The fate of tropical forests: A matter of stewardship. Conservation Biology, 14, 1358-1361.

United Nations Environment Programme \& World Conservation Monitoring Centre. (2008). Whale sanctuary of El VIzcaino Mexico. World Heritage Sites. Protected Areas and World Heritage, 1-5.

US FWS. (1967). Endangered Species Act. Retrieved from http://ecos.fws.gov/speciesProfile/profile/ speciesProfile. action?spcode=A009

West, P., Igoe, J., \& Brockington, D. (2006). Parks and peoples: The social impact of protected areas. Annual Review of Anthropology, 35, 251-277. doi:10.1146/annurev.anthro.35.081705.123308

Woodruff, D. S. (2010). Biogeography and conservation in Southeast Asia: how 2.7 million years of repeated environmental fluctuations affect today's patterns and the future of the remaining refugial-phase biodiversity. Biodiversity Conservation, 19, 919-941. doi:10.1007/s10531-0109783-3

Young, E. (1999). Local people and conservation in Mexico's El Vizcaíno Biosphere Reserve. The Geographical Review, 89, 364-390. 